\title{
Adenosine Triphosphate Stimulates Phosphoinositide Metabolism, Mobilizes Intracellular Calcium, and Inhibits Terminal Differentiation of Human Epidermal Keratinocytes
}

\author{
Sreekumar Pillai and Daniel D. Bikle \\ Departments of Medicine and Dermatology, University of California, San Francisco, \\ and Veterans Administration Medical Center, San Francisco, California 94121
}

\begin{abstract}
During wound healing, release of ATP from platelets potentially exposes the epidermis to concentrations of ATP known to alter cellular functions mediated via changes in inositol trisphosphate $\left(\mathrm{IP}_{3}\right)$ and intracellular calcium (Cai) levels. Therefore, we determined whether keratinocytes respond to ATP with a rise in Cai and $\mathrm{IP}_{3}$ and whether such increases are accompanied by a change in their proliferation and differentiation. Changes in Cai were measured in Indo-1-loaded neonatal human foreskin keratinocytes after stimulation with extracellular ATP. Extracellular ATP evoked a transient and acute increase in Cai of keratinocytes both in the presence and in the absence of extracellular calcium. ATP also induced the phosphoinositide turnover of keratinocytes, consistent with its effect in releasing calcium from intracellular sources. ATP did not permeabilize keratinocytes, nor did it promote $\mathrm{Ca}$ influx into the cells. The half-maximal effect of ATP was at $10 \mu \mathrm{M}$, and saturation was observed at 30-100 $\mu \mathrm{M}$. UTP, ITP, and ATP $\gamma \mathrm{S}$ were as effective as ATP in releasing Cai from intracellular stores and competed with ATP for their response, whereas AMP and adenosine were ineffective, suggesting the specificity of $P_{2}$ purinergic receptors in mediating the ATP response in keratinocytes. Single cell measurements revealed heterogeneity in the calcium response to ATP. This heterogeneity did not appear to be due to differences in the initial Cai response but to subsequent removal of increased Cai by these cells. ATP inhibited terminal differentiation of keratinocytes as measured by ${ }^{35}$ S]methionine incorporation into cornified envelopes and modestly stimulated incorporation of $\left[{ }^{3} \mathrm{H}\right]$ thymidine into DNA. Chelation of Cai by bis-(o-aminophenoxy)- $N, N, N^{\prime}, N^{\prime}$-tetraacetic acid reduced basal Cai, blocked the Cai response to ATP, inhibited the basal rate of DNA synthesis, and blocked the ATP-induced increase in DNA synthesis. We conclude that extracellular ATP may be an important physiological regulator of epidermal growth and differentiation acting via $\mathrm{IP}_{\mathbf{3}}$ and Cai. (J. Clin. Invest. 1992. 90:42-51.) Key words: adenosine triphosphate $\bullet$ human keratinocytes $\bullet$ intracellular calcium • terminal differentiation $\bullet$ phosphoinositide metabolism
\end{abstract}

\section{Introduction}

Extracellular ATP at low micromolar concentrations influences many biological processes (1) including platelet aggregation (2), vascular tone $(3,4)$, neurotransmission $(5,6)$ and mus-

Address correspondence to Sreekumar Pillai, Ph.D., Department of Dermatology (190), Veterans Affairs Medical Center, 4150 Clement Street, San Francisco, CA 94121.

Received for publication 6 August 1990 and in revised form 23 January 1992.

The Journal of Clinical Investigation, Inc.

Volume 90, July 1992, 42-51 cle contraction (7). Plasma concentrations of ATP can achieve the micromolar range under certain conditions such as secretion from platelets $(8,9)$, purinergic nerves $(10)$, and adrenal medulla (11). The extracellular ATP interacts with a subclass of purinergic receptors (P2 purinergic receptors) on the cell surface which are specific for ATP (12-15). Recent studies have indicated that extracellular ATP activates $P_{2}$ purinergic receptor-operated calcium channels in arterial smooth muscle cells increasing intracellular free calcium levels (Cai) ${ }^{1}(16)$. Similar effects of ATP on Cai have been shown in adipocytes (17), liver epithelial cells (18), A431 epidermoid carcinoma cells (19), HL-60 cells (20), and canine keratinocytes (21). In HL-60 cells ATP increases Cai via the production of inositol trisphosphate (20). ATP acts synergistically with other growth factors such as platelet-derived growth factor (PDGF), transforming growth factor- $\alpha$ (TGF- $\alpha$ ), and epithelial growth factor (EGF) to enhance DNA synthesis in a variety of cell types $(22,23)$. In some cells, such as A431 cells, a protein kinase C-dependent pathway is partially involved (24), but in other cells (3T3, 3T6) prostaglandin $\mathrm{E}_{2}\left(\mathrm{PGE}_{2}\right)$ synthesis followed by elevation of cAMP levels is responsible for the mitogenic response of ATP (25).

Changes in Cai levels mediate the cellular effects of hormones and growth factors (26-28). A role for Cai in cell proliferation is suggested (29) by the observation that events during cell division such as formation of the mitotic apparatus (30), transformation of spindle-associated proteins (31), and the onset of anaphase (32) are accompanied by changes in Cai. A role for Cai during differentiation of keratinocytes in culture is well established (33-35). Extracellular calcium evokes a sustained increase of intracellular calcium levels in keratinocytes (36-38) and induces their terminal differentiation. Calcium ionophores in the presence of adequate extracellular calcium rapidly raise Cai and induce terminal differentiation (38). Therefore, if ATP were to alter the Cai in keratinocytes it could affect their rates of proliferation or differentiation.

In this study, we evaluated whether extracellular ATP alters Cai in keratinocytes, and whether this action is associated with a change in keratinocyte growth or differentiation. We found that extracellular ATP evoked a rapid and transient mobilization of calcium from intracellular sources in keratinocytes which paralleled a rise in inositol triphosphate $\left(\mathrm{IP}_{3}\right)$ formation. This transient increase in Cai was associated with a substantial reduction in cornified envelope formation and a modest shortterm stimulation in DNA synthesis. These studies suggest that extracellular ATP released from platelets during skin wound-

1. Abbreviations used in this paper: BAPTA AM, bis-(o-aminophenoxy)- $N, N, N^{\prime}, N^{\prime}$, tetraacetic acid acetoxymethylester; BPE, bovine pituitary extract; Cai, intracellular calcium; EGF, epidermal growth factor; Indo-1 AM, Indo-1 acetoxymethylester; $\mathrm{IP}_{3}$, inositol triphosphate; KGM, keratinocyte growth medium; PDGF, platelet-derived growth factor; TGF- $\alpha$, transforming growth factor- $\alpha$. 
ing may stimulate reepithelialization by inhibiting the differentiation of keratinocytes mediated via changes in Cai.

\section{Methods}

Materials. Indo-1 acetoxymethylester (Indo-1 AM) and the intracellular calcium chelator bis-( $O$-aminophenoxy)- $N, N, N^{\prime}, N^{\prime}$-tetraacetic acid acetoxymethylester (BAPTA-AM) were purchased from Molecular Probes (Junction City, OR). Ionomycin was purchased from Calbiochem Corp. (La Jolla, CA). Crystalline ATP sodium salt, propidium iodide, and all other chemicals were purchased from Sigma Chemical Co. (St. Louis, MO).

Cell culture. Second passage keratinocytes isolated from neonatal human foreskins were used in these studies. They were grown in serumfree keratinocyte growth medium (KGM) obtained from Clonetics Corp. (San Diego, CA) as described previously (34). Briefly, keratinocytes were isolated from newborn human foreskins using $0.25 \%$ trypsin, and the primary cultures were grown to confluence in KGM containing $0.07 \mathrm{mM}$ calcium before passaging them into $\mathrm{KGM}$ containing either $0.07 \mathrm{mM}$ or $1.2 \mathrm{mM}$ calcium. Cells were evaluated at confluence.

Measurement of Cai. Keratinocytes were dispersed using $0.1 \%$ tryp$\sin / 0.01 \%$ EDTA, and trypsin was neutralized with soybean trypsin inhibitor (Sigma Chemical Co., St. Louis, MO). After washing, the cells were suspended in $20 \mathrm{mM}$ Hepes buffer pH 7.4 containing $120 \mathrm{mM}$ sodium chloride, $5 \mathrm{mM}$ potassium chloride, $1 \mathrm{mM}$ magnesium chloride, $1 \mathrm{mg} / \mathrm{ml}$ pyruvate, $1 \mathrm{mg} / \mathrm{ml}$ glucose, and $0.03 \mathrm{mM}$ calcium chloride (buffer A) at a cell concentration of $1-1.5 \times 10^{6}$ cells $/ \mathrm{ml}$. Indo-1 AM was added to a final concentration of $2 \mu \mathrm{M}$ from a stock solution in DMSO and incubated at $35^{\circ} \mathrm{C}$ for $1 \mathrm{~h}$. In experiments using BAPTA, $18 \mu \mathrm{M}$ BAPTA-AM (final concentration) in DMSO was added $15 \mathrm{~min}$ after Indo-1 addition. Cells were then washed three times with buffer $A$ and resuspended in buffer $A$ at the original cell concentration of 1-1.5 million cells per milliliter. Cells were washed and resuspended in fresh buffer A before each measurement, and all the measurements were completed within 2-2.5 h after Indo-1 loading. Cells studied in this fashion show little Indo-1 leakage. Fluorescence was recorded with a Perkin-Elmer 650-40 fluorimeter (Perkin-Elmer Corp., Norwalk, CT) using $350 \mathrm{~nm}$ and $405 \mathrm{~nm}$ for excitation and emission wavelengths, respectively, with a thermostatted cuvette $\left(37^{\circ} \mathrm{C}\right)$, equipped with a magnetic stirrer. Fluorescence signals were recorded by a chart recorder continuously after each addition, and calibrated for each sample by the addition of ionomycin ( $10 \mu \mathrm{M}$ final concentration) (maximum fluorescence, $F_{\max }$ ) followed by $0.1 \%$ Triton X-100 and $10 \mathrm{mM}$ EGTA/Tris pH 8.3 (minimum fluorescence, $F_{\min }$ ). Cai was calculated from the following formula: Cai $=K_{\mathrm{d}}\left(\mathrm{F}-\mathrm{F}_{\min }\right) /\left(\mathrm{F}_{\max }-\mathrm{F}\right)$ where $K_{\mathrm{d}}$ for Indo-1 for $\mathrm{Ca}$ is $250 \mathrm{nM}$ (39). Additions of ATP, Mn, ionomycin, or other agents were done from concentrated solutions such that changes in volume were minimal with each addition. Typically, ATP was added from a stock solution of $10 \mathrm{mM}$ in distilled water made fresh each day.

Cai measurements in attached cells. Cai levels of keratinocytes attached to glass cover slips were measured using a laser-based fluorescence image analyzer system from Meridian Instruments (Okemos, MI). The cells attached to special cover slips of $1 \mathrm{~mm}$ thickness were loaded with $1 \mu \mathrm{M}$ Indo-1 AM and mounted on the stage of an inverted fluorescence microscope. Scanning of the cells in a field of view was achieved by moving the stage in a $x$-y pattern past a focused laser beam of $1 \mu \mathrm{m}$ diameter which illuminates the cell for $8 \mu \mathrm{s}$ at an excitation wavelength of 351-363 nm. The fluorescence emitted was detected simultaneously by two photomultiplier tubes, one set at wavelength maxima for the Ca:Indo- 1 complex $(405 \mathrm{~nm})$ and the other set for free Indo-1 $(485 \mathrm{~nm})$. The ratio of $405: 485$ was used for the Cai calculation. The use of ratio analysis eliminates artifacts due to cell thickness, differential loading, photodynamic damage, or dye leakage. The data were processed by computer and presented as pseudo color images.

Phosphoinositide metabolism of keratinocytes. Turnover of inositol phosphates was measured by a modification of the method by Berridge et al. (40). Briefly, confluent cultures of keratinocytes in six well multiwell plates were prelabeled with $1 \mu \mathrm{Ci} / \mathrm{ml}$ of $\left[{ }^{3} \mathrm{H}\right]$ myoinositol (Amersham Corp., Arlington, IL) (sp act $18 \mathrm{Ci} / \mathrm{mmol}$ ) in an inositol-free DMEM for $72 \mathrm{~h}$. After washing, the cells were preequilibrated for $5 \mathrm{~min}$ with $1 \mathrm{ml}$ of DMEM containing $20 \mathrm{mM}$ Hepes buffer $\mathrm{pH} 7.4$ and 10 $\mathrm{mM}$ lithium chloride, then treated with $100 \mu \mathrm{M}$ ATP for the various time periods indicated. The reaction was stopped by aspiration of the medium and addition of ice-cold 10\% TCA. Cells were scraped from the dish, TCA was extracted with diethyl ether, and inositol phosphates were separated using Dowex 1-X8 (Bio-Rad Laboratories, Richmond, CA) columns eluted with stepwise gradients of ammonium formate buffers. $\mathrm{IP}_{1}, \mathrm{IP}_{2}$, and $\mathrm{IP}_{3}$ levels were quantitated by counting the appropriate column fractions. IP levels of control cells and ATP treated cells were determined in parallel, and the results were plotted as percent change over control for each time point.

Permeability measurement of keratinocytes using propidium iodide. The permeability of keratinocytes exposed to various ATP concentrations was determined by the uptake of the nuclear stain propidium iodide. This stain is impermeable to cells and emits fluorescence only when bound to DNA. Trypsinized keratinocytes in suspension were incubated in the medium with $25 \mu \mathrm{M}$ propidium iodide, and the fluorescence was measured at excitation and emission wavelengths of 365 and 588, respectively. At the end of the experiment, Triton X-100 was added to permeabilize the cells as a positive control.

Growth and differentiation markers. Cellular DNA was assayed by the method of Labarca and Paigan (41) using the fluorescent reagent, bis benzimidazole. $\left[{ }^{3} \mathrm{H}\right]$ thymidine incorporation into DNA was quantitated by two methods. In the first method, the cells were incubated with $2 \mu \mathrm{Ci} / \mathrm{ml}$ medium of $\left[{ }^{3} \mathrm{H}\right]$ thymidine (Amersham Corp.; sp act 42 $\mathrm{Ci} / \mathrm{mmol}$ ) for $3 \mathrm{~h}$ at $37^{\circ} \mathrm{C}$ and the amount of label associated with TCA-precipitable macromolecules was determined by scintillation spectroscopy. In the second method, the number of cell nuclei labeled with $\left[{ }^{3} \mathrm{H}\right]$ thymidine was quantitated. Keratinocytes in four-well chamber slides were labeled with $\left[{ }^{3} \mathrm{H}\right]$ thymidine as described before. Slides were then fixed with $10 \%$ formaldehyde, washed with PBS, coated with K. 5D photographic emulsion (Polysciences Inc., Warrington, PA), and autoradiographed. Cells were lightly stained with toluidine blue, and the number of labeled nuclei and the total number of cells were counted in five different fields under the microscope. The data are expressed as the percent labeled nuclei of total cells.

Cornified envelope formation, a marker for the terminal differentiation of keratinocytes, was determined by the method of King et al. (42). In this method, the cornified envelope precursor proteins were labelled with $\left[{ }^{35} \mathrm{~S}\right]$ methionine by incubating cultures with $\left[{ }^{35} \mathrm{~S}\right]-\mathrm{L}$ methionine $(2 \mu \mathrm{Ci} / \mathrm{ml}$ medium $)$ for $48 \mathrm{~h}$. These precursors were cross-linked by the epidermal transglutaminase to form a detergent-insoluble, thickened envelope which surrounds the terminally differentiated keratinocytes. The rate of formation of the envelope in the 48-h period was then determined by dissolving the cells in $2 \%$ SDS/20 mM DTT by boiling for $10 \mathrm{~min}$ and quantitating the amount of radioactivity present in the insoluble material. The amount of $\left[{ }^{35} \mathrm{~S}\right]$ methionine incorporated into total cellular proteins was determined by quantitating the radioactivity in an aliquot of the cell homogenate precipitated with $10 \%$ TCA

Statistical analysis for the effects of ATP was performed by analysis of variance using the appropriate programs in SYSTAT (Systat, Inc., Evanston, IL).

\section{Results}

Extracellular ATP raises Cai levels of keratinocytes. Stimulation of keratinocytes with $100 \mu \mathrm{M}$ ATP elicited a rapid increase in Cai within seconds. The increase in Cai reached a peak value which is typically 2-2.5-fold higher than the basal Cai level within 10-15 s following addition of ATP. Thereafter, the Cai declined quickly to below basal level within 1-2 min before returning to the initial basal level (Fig. $1 A$ ). In the absence of extracellular calcium ( $1 \mathrm{mM}$ EGTA), the resting Cai levels 


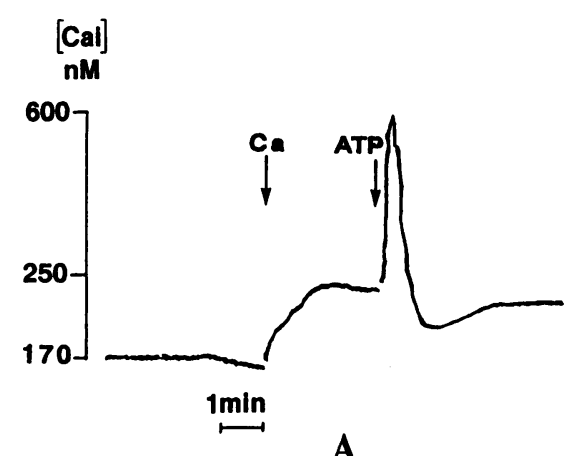

A
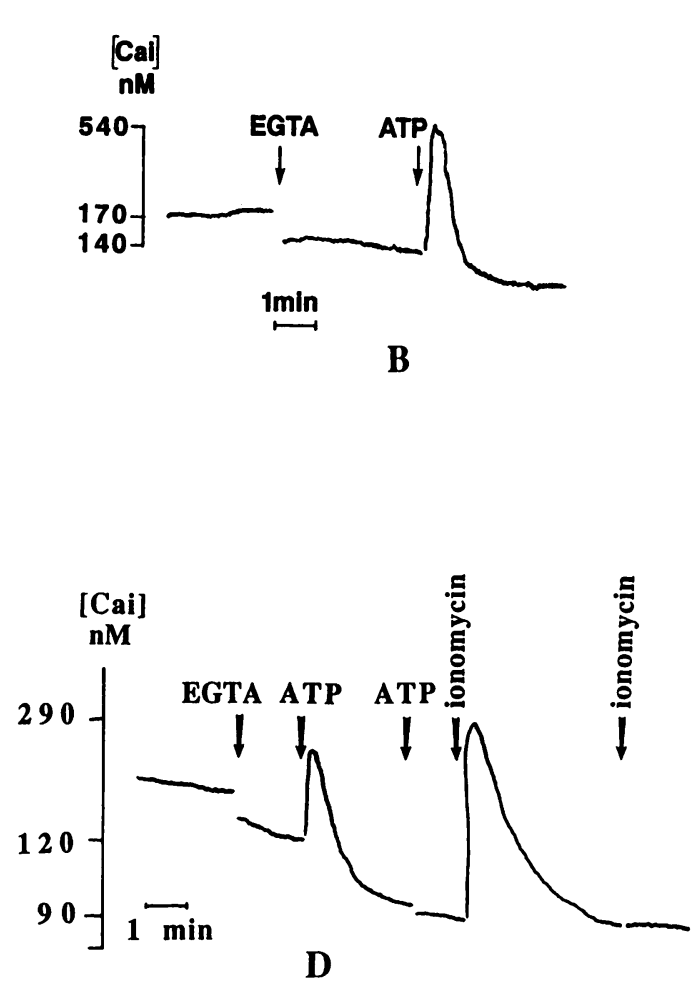

Figure 1. Effect of extracellular ATP on Cai of keratinocytes. $100 \mu \mathrm{M}$ ATP was added to keratinocytes loaded with $2 \mu \mathrm{M}$ Indo-1 AM in $0.03 \mathrm{mM} \mathrm{Cao}$, and the fluorescence changes ( 350 $\mathrm{nm}$ excitation/405 nm emission) were noted. Cells were exposed to ATP after the addition of $2.0 \mathrm{mM} \mathrm{CaO}(A)$, or $1.0 \mathrm{mM}$ EGTA $(B)$. In $C$, cells in $1.0 \mathrm{mM}$ EGTA were first exposed to $10 \mu \mathrm{M}$ ionomycin followed by $100 \mu \mathrm{M}$ ATP. In the experiment represented in $D$, cells in $1 \mathrm{mM}$ EGTA were exposed to 100 $\mu \mathrm{M}$ each of ATP two times followed by $10 \mu \mathrm{M}$ ionomycin two times. Each tracing is representative of at least 10 different experiments done at different times with different cell preparations. Calculated Cai values are given at the left side of each figure. The additions were made as indicated at the arrows. were slightly lower, but ATP evoked a similar response in Cai as in the presence of $1.2 \mathrm{mM}$ Calcium (Fig. $1 \mathrm{~B}$ ). This indicates that this ATP-induced increase in Cai is from intracellular sources. When the intracellular calcium pools of keratinocytes were depleted by a calcium ionophore, ionomycin, in the presence of $1 \mathrm{mM}$ EGTA, ATP failed to evoke a Cai response, confirming the intracellular source of calcium for ATP-mediated release (Fig. $1 C$ ). Repetitive additions of ATP to cells following $100 \mu \mathrm{M}$ initial addition failed to raise Cai after the initial effect, although subsequent addition of ionomycin evoked a pronounced increase in Cai (Fig. $1 D$ ). However, exposure of cells to initial subsaturating levels of ATP $(<10 \mu \mathrm{M})$ permitted a second response to $100 \mu \mathrm{M}$ ATP (data not shown). A dose-response curve for ATP (Fig. 2) confirms that 30-100 $\mu \mathrm{M}$ ATP exerts maximal stimulation with half-maximal stimulation by $10 \mu \mathrm{M}$ ATP. This suggests the presence of purinergic receptors on the keratinocyte cell surface capable of being desensitized by ATP and with an approximate $K_{d}$ of $10 \mu \mathrm{M}$. To test the specificity of these purinoreceptors, the cells were exposed first to $100 \mu \mathrm{M}$ of different nucleotide analogues followed by $100 \mu \mathrm{M}$ ATP, 5 min later (Table I). ITP, UTP, and ATP $\gamma \mathrm{S}$ displayed similar responses as ATP and desensitized the cells to ATP, suggesting competition for the same receptor. GTP and CTP also rised Cai of keratinocytes but to a lower extent, and failed to block the ATP response, suggesting that the effect of these nucleotides is mediated by a different receptor. Other nucleotide and polyphosphate analogues such as $\operatorname{AMP}(\beta, \gamma$ methyl $) \mathrm{PP}$, diadenine triphosphate, methyl xanthine, AMP, GMP, and sodium pyrophosphate, failed to elicit a Cai response or block ATP response.

To test whether ATP also increases an inflow of calcium into the cell from extracellular sources, experiments shown in Fig. 3 were carried out. The divalent cation $\mathrm{Mn}^{++}$enters cells via divalent cation channels on the plasma membrane (43). In contrast to $\mathrm{Ca}$ ions, $\mathrm{Mn}$ binding to Indo-1 causes quenching of the fluorescence. Therefore, the rate of quenching of Indo-1 fluorescence by $\mathrm{Mn}$ can be used as a measure of unidirectional calcium uptake by cells. As seen in Fig. $3 \mathrm{~A}$, Mn alone caused a progressive decrease in fluorescence. Treatment of cells with $100 \mu \mathrm{M}$ ATP before Mn addition did not change the Mn

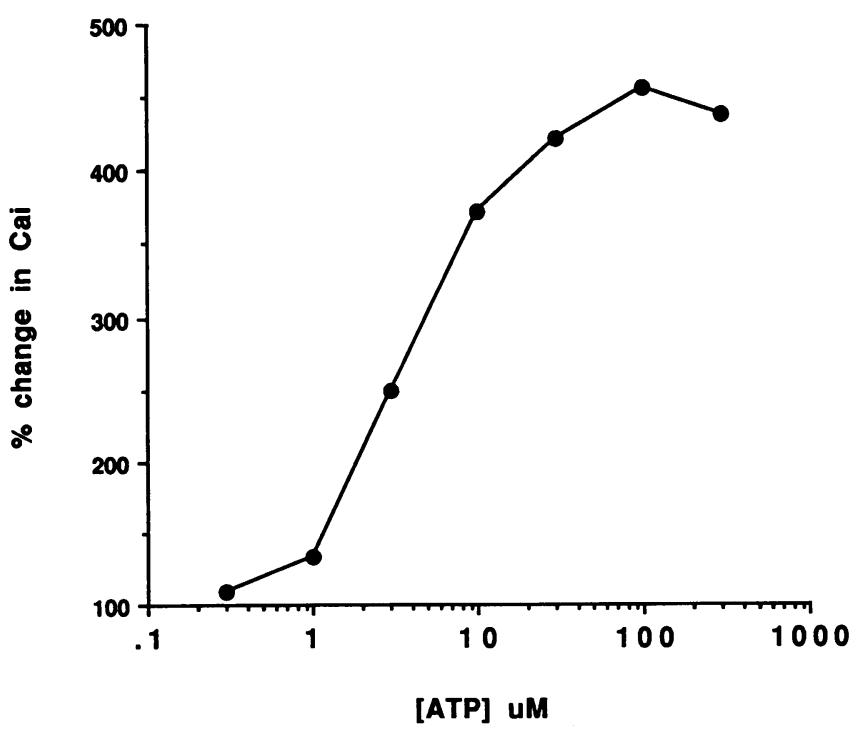

Figure 2. Dose-response curve for ATP to Cai. Intracellular calcium levels of Indo-1 AM loaded keratinocytes were measured after exposure to $1-300 \mu \mathrm{M}$ ATP. The results are the average of duplicate determinations. 
Table I. Cai Changes with ATP and the Different Nucleotide Analogues

\begin{tabular}{|c|c|c|}
\hline \multicolumn{2}{|c|}{ First addition } & \multirow{2}{*}{$\frac{\text { Second addition of ATP }}{\text { Percent change in Cai }}$} \\
\hline Analogue & Percent change in Cai & \\
\hline ATP & 76 & 0 \\
\hline ITP & 72 & 0 \\
\hline UTP & 80 & 0 \\
\hline $\mathrm{ATP} \gamma \mathrm{S}$ & 76 & 0 \\
\hline AMP pNp & 23 & 38 \\
\hline ADP & 48 & 18 \\
\hline CTP & 26 & 37 \\
\hline GTP & 23 & 39 \\
\hline Methyl xanthine & 0 & 80 \\
\hline Diadenyl triphosphate & 0 & 76 \\
\hline Na pyrophosphate & 0 & 88 \\
\hline AMP & 0 & 79 \\
\hline GMP & 0 & 85 \\
\hline Adenosine & 0 & 86 \\
\hline $\operatorname{ATP}(\beta, \gamma$ methyl $)$ PP & 0 & 80 \\
\hline
\end{tabular}

Basal Cai level was 172-185 nM. Cells were first exposed to $100 \mu \mathrm{M}$ each of the different compounds (first addition), followed 5 min later with $100 \mu \mathrm{M}$ ATP. The peak of Cai obtained with each compound (between 20 and $40 \mathrm{~s}$ ) was calculated and expressed as percent change over basal. Each compound was tested in at least two separate cell preparations. The results shown are from one experiment.

quenching of Indo-1 fluorescence (Fig. $3 \mathrm{~B}$ ). However, ionomycin evoked a rapid quenching of Indo-1 fluorescence by $\mathrm{Mn}$ (Fig. $3 C$ ). Addition of ATP or ionomycin following Mn addition gave similar results in that ATP did not alter the Mn quenching but ionomycin induced a rapid quenching of the Indo-1 fluorescence (Fig. 3, $D$ and $E$ ). Furthermore, $\mathrm{Mn}$ did not reduce the rapid rise in fluorescence following ATP (unlike that following ionomycin). Calcium channel blockers or depolarization by potassium were without effect on the ATP induced increase in Cai (data not shown). These studies confirm that ATP mobilizes calcium from intracellular sources with little effect on calcium influx.

Extracellular ATP stimulates the inositol phosphate turnover of keratinocytes. It is well established that inositol 1,4,5trisphosphate $\left(\mathrm{IP}_{3}\right)$ triggers $\mathrm{Ca}$ release from intracellular stores $(40,44)$. Extracellular ATP stimulates the formation of $\mathrm{IP}_{3}$ and triggers increases in Cai levels in Ehrlich ascites tumor cells (45), HL-60 cells (20), and endothelial cells (46). To determine if ATP stimulates $\mathrm{IP}_{3}$ turnover in keratinocytes, we labeled these cells with $\left[{ }^{3} \mathrm{H}\right]$ myo-inositol as described in Methods. Labeled keratinocytes were incubated with $100 \mu \mathrm{M}$ ATP for 15 , $30 \mathrm{~s}, 1,2$, and $5,10,20$, and $30 \mathrm{~min}$, and the production of $\mathrm{IP}_{1}$, $\mathrm{IP}_{2}$, and $\mathrm{IP}_{3}$ was measured. As shown in Fig. 4, extracellular ATP stimulated inositol phosphate formation. $\mathrm{IP}_{1}$ production was minimal in the first $2 \mathrm{~min}$. By $10 \mathrm{~min} \mathrm{IP}_{1}$ levels increased to 2.5-3-fold higher than basal and remained elevated for up to $20 \mathrm{~min}$ (Fig. $4 \mathrm{~A}$ ). $\mathrm{IP}_{2}$ generation was stimulated as early as $30 \mathrm{~s}$ after ATP addition, and peaked by $10 \mathrm{~min}$ followed by a decline to basal levels by $30 \mathrm{~min}$. $\mathrm{IP}_{3}$ generation was increased even at the earliest time period ( $15 \mathrm{~s})$, was maximal as early as $30 \mathrm{~s}$ (1.5-2-fold above basal levels) (Fig. $4 \mathrm{~B}$ ) and remained elevated for up to $2 \mathrm{~min}$ followed by a decline to basal levels by
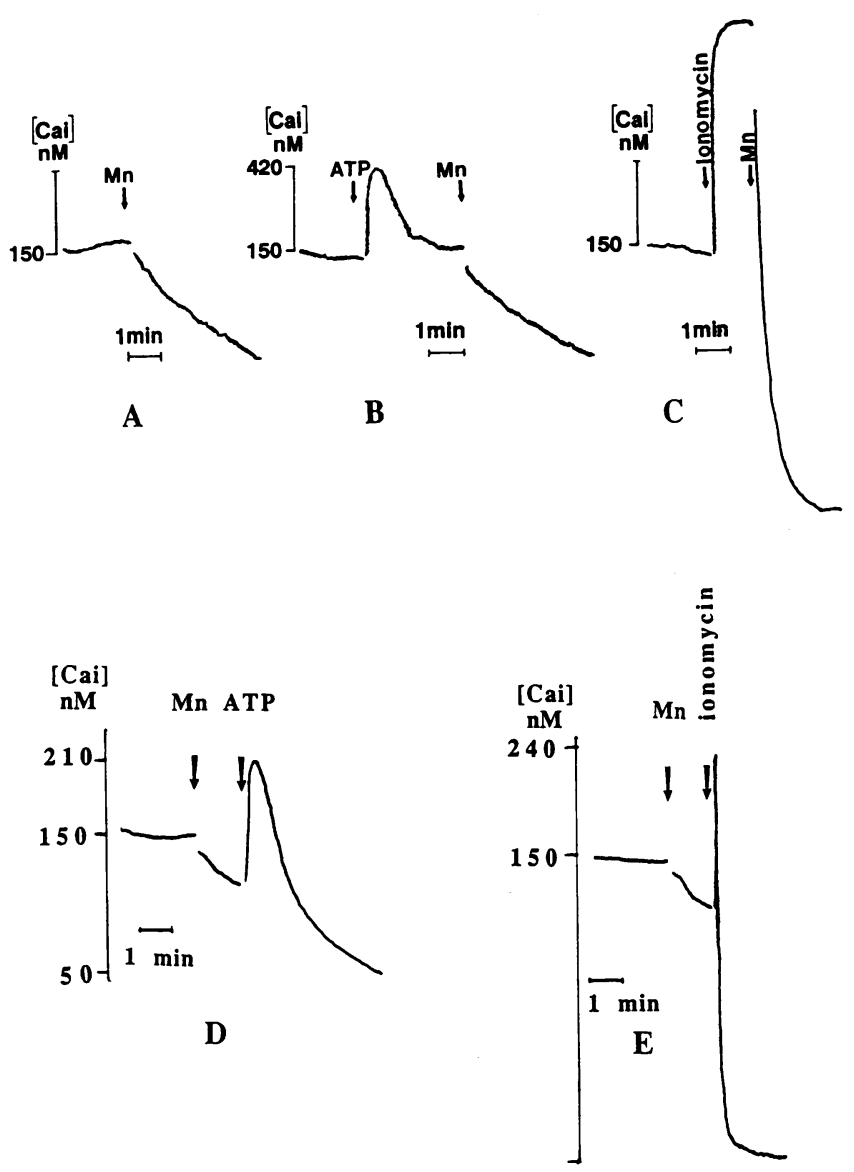

Figure 3. Effect of ATP on Mn quenching of Indo-1 fluorescence of keratinocytes. Keratinocytes loaded with Indo-1 AM suspended in $0.03 \mathrm{mM}$ Cao were exposed to $300 \mu \mathrm{M}$ manganese chloride, and the change in fluorescence was noted $(A)$. Cells were first exposed to 100 $\mu \mathrm{M}$ ATP and then to $300 \mu \mathrm{M} \mathrm{Mn}(B)$ or first to $10 \mu \mathrm{M}$ ionomycin then to $\mathrm{Mn}(C)$. In experiments represented in $D$ and $E$, cells were first exposed to $300 \mu \mathrm{M}$ Mn before ATP $(D)$ or ionomycin $(E)$. Data shown are representative of three separate experiments.

20-30 min. The time scale of $\mathrm{IP}_{3}$ generation was similar to that of the effect of ATP on Cai.

Extracellular ATP does not permeabilize keratinocytes. A nonlethal permeabilizing effect of ATP has been shown in several cell systems in the absence of extracellular divalent cations. To test whether the effect of ATP on increasing Cai of keratinocytes is due to such a nonspecific effect, we evaluated propidium iodide entry into cells in the presence of increasing concentrations of ATP. As demonstrated in Fig. 5, there was no increase in the entry of propidium iodide into keratinocytes with ATP up to millimolar concentrations. $0.05 \%$ Triton $\mathrm{X}-100$ markedly increased the entry of the dye into cells as seen by an increase in fluorescence. These results and the $\mathrm{Mn}^{++}$ permeability studies (Fig. 3) indicate that extracellular ATP does not permeabilize keratinocytes.

Keratinocytes are heterogeneous in their response to ATP. Keratinocytes grown in physiological calcium concentrations contain a mixed population of cells, with some undifferentiated cells and others in various stages of differentiation (47). To determine whether this heterogeneity is reflected in their response to ATP, we determined the Cai response of keratino- 

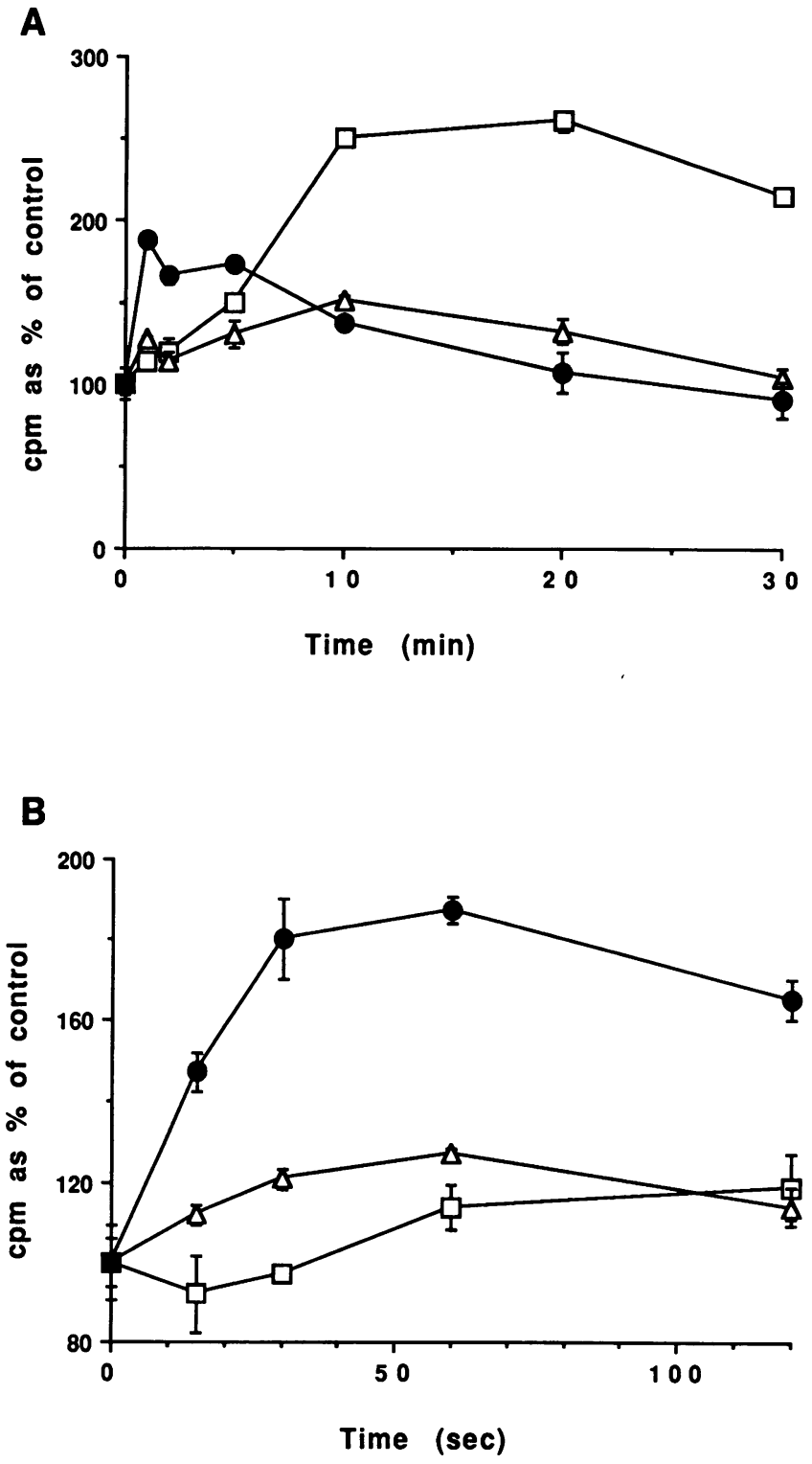

Figure 4. Effect of ATP on phosphoinositide turnover of keratinocytes. Keratinocytes attached to dishes were prelabeled with $\left[{ }^{3} \mathrm{H}\right]-$ myo-inositol for $72 \mathrm{~h}$ in myo-inositol-free DMEM as described in Methods. The labeled cells were treated with $100 \mu \mathrm{M}$ ATP for various time periods in the presence of $10 \mathrm{mM}$ lithium chloride. The inositol phosphates from the cells were extracted and quantitated. The changes in IP are expressed as percent change above 0 time for each of the three IPs \pm SEM of three determinations. The amount of IPs generated at 0 time were $7,207 \mathrm{cpm} / 10^{6}$ cells $\mathrm{IP}_{1}, 5,593 \mathrm{cpm} / 10^{6}$ cells $\mathrm{IP}_{2}$, and $2,613 \mathrm{cpm} / 10^{6}$ cells $\mathrm{IP}_{3} . A$ represents the time course for 30 $\mathrm{min}$, and $B$ represents the time course for the first $2 \mathrm{~min}$. $\left(\square, \mathrm{IP}_{1} ; \Delta\right.$, $\left.\mathrm{IP}_{2} ; \bullet, \mathrm{IP}_{3}\right)$. IP levels of control cells not treated with ATP did not change significantly over the time period of the experiment.

cytes to ATP using imaging analysis of a population of cells. Fig. 6 shows the Cai image of a group of keratinocytes grown in $0.07 \mathrm{mM}$ extracellular calcium. The resting Cai level was $\sim 120-140 \mathrm{nM}$. When $100 \mu \mathrm{M}$ ATP was added, the Cai levels increased acutely as in the cuvette measurements. The effect was transient as in the cuvette measurements, but the achievement of basal level varied between cells. In the sequence of

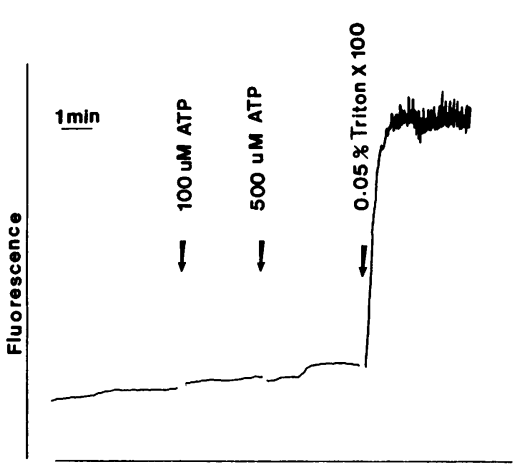

Figure 5. Effect of ATP on the permeability of keratinocytes. Keratinocytes were suspended in a medium containing $25 \mu \mathrm{M}$ propidium iodide, and the fluorescence was noted as described. The cells were exposed to $100 \mu \mathrm{M}$ ATP and $500 \mu \mathrm{M}$ ATP before permeabilizing with $0.05 \%$ Triton X-100. The changes in fluorescence were noted.

pictures in Fig. 6, $30 \mathrm{~s}$ after the addition of $100 \mu \mathrm{M}$ ATP all the cells responded to ATP by an acute increase in Cai. The Cai levels at $30 \mathrm{~s}$ were $600-800 \mu \mathrm{M}$. These levels were higher than the ATP induced Cai levels observed in the cell suspension experiments (Figs. 1 and 2). 3 min after the ATP addition, Cai of some of the cells (Fig. $6 \mathrm{C}$ ) returned to basal while other cells were still higher than basal. By 6 min, most cells returned to basal Cai levels. It appears from these studies that the heterogeneity observed in keratinocytes is not due to the initial ATP induced Cai increase, but is due to variations in the removal mechanism of the Cai. This was confirmed using ionomycin in the presence of EGTA, in which case the Cai of all cells increased acutely (in $30 \mathrm{~s}$ ) well beyond $800 \mu \mathrm{M}$, but the cells again showed heterogeneity in their return phase to basal Cai (data not shown). However, the possibility of variations in the initial response of cells to ATP cannot be ruled out entirely because the earliest time point that can be measured by this method is $30 \mathrm{~s}$ after the addition of the agents. Thus, these studies confirmed the Cai response of keratinocytes to extracellular ATP and indicated that keratinocytes may be heterogeneous in their ability to remove or sequester calcium following an acute increase in Cai.

Extracellular ATP stimulates proliferation and inhibits differentiation of keratinocytes. Exposure of keratinocytes to ATP for $8 \mathrm{~d}$ from the day after plating dramatically inhibited the rate of cornified envelope formation of keratinocytes as measured by the rate of cross-linking of $\left[{ }^{35} \mathrm{~S}\right]$ methionine prelabeled envelope precursor proteins into the detergent insoluble cornified envelopes (Table II). The total number of cells (DNA content) or the amount of $\left[{ }^{35} \mathrm{~S}\right]$ methionine incorporation into total cellular proteins was unaffected for all concentrations of ATP except $300 \mu \mathrm{M}$, indicating that ATP up to $100 \mu \mathrm{M}$ was not toxic to cells. Exposure of keratinocytes acutely to ATP (3-300 $\mu \mathrm{M})$ modestly increased DNA synthesis $\left(\left[{ }^{3} \mathrm{H}\right]\right.$ thymidine incorporation) without affecting the total DNA content after $2 \mathrm{~d}$ of exposure (Table III). To confirm these effects on proliferation, we compared the effects of ATP to that of bovine pituitary extract (BPE) and FCS on keratinocyte DNA synthesis and DNA content (Table IV and Fig. 7). DNA content and $\left[{ }^{3} \mathrm{H}\right]-$ thymidine incorporation into DNA were lower in control cells grown for $5 \mathrm{~d}$ in the absence of BPE when compared to BPEsupplemented medium ( $70 \mu \mathrm{g}$ protein/ml medium). FCS stimulated both the DNA synthesis rate (175\% above control) and the total DNA content ( $200 \%$ above control) of keratinocytes. $100 \mu \mathrm{M}$ ATP acutely stimulated the DNA synthesis rate $(50 \%$ above control), but did not significantly affect the DNA content of the cultures after $5 \mathrm{~d}$ of treatment. Autoradiography of 

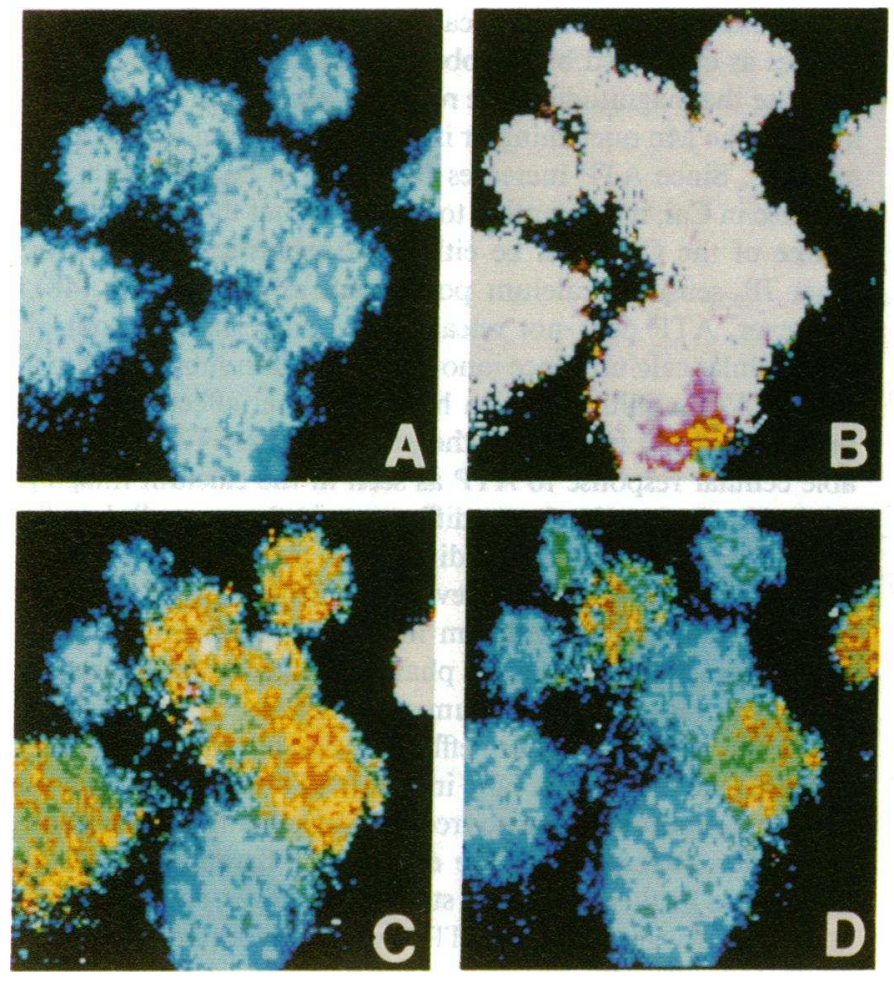

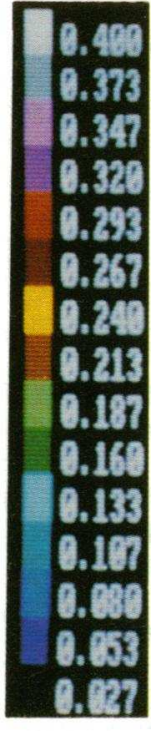

Figure 6. Fluorescence imaging of intracellular calcium distribution in keratinocytes. Keratinocytes grown on glass cover slips were loaded with Indo-1 AM, and the fluorescence image of the cells before and after $100 \mu \mathrm{M}$ ATP treatment was measured using a fluorescence image analyzer system from Meridian Instruments. Images of a group of keratinocytes were taken at 0 time $(A)$, $30 \mathrm{~s}(B), 3 \mathrm{~min}(C)$, and $6 \mathrm{~min}(D)$ after $100 \mu \mathrm{M}$ ATP. Experiments shown are representative of three different measurements done on different cell preparations. labeled cells also confirmed the biochemical data on DNA synthesis in that ATP modestly stimulated DNA synthesis while FCS and BPE showed a greater extent of stimulation. These studies indicate that ATP transiently stimulates keratinocyte proliferation, while inhibiting their differentiation.

To determine whether ATP-induced DNA synthesis is me-

Table II. Effect of ATP on $I^{35}$ SJMethionine Incorporation into Total Cellular Proteins and Cornified Envelopes of Keratinocytes

\begin{tabular}{rccc} 
ATP & DNA & $\begin{array}{c}{[35] \text { Methionine into }} \\
\text { total cell proteins }\end{array}$ & $\begin{array}{c}{ }^{35} \text { Methionine into } \\
\text { cornified envelopes }\end{array}$ \\
\hline$\mu M$ & $\mu g / d i s h$ & Percent of control & $c p m / \mu g$ DNA \\
0 & $16.5 \pm 1.9$ & $100 \pm 1.9$ & $1445 \pm 85$ \\
3 & $15.1 \pm 2.2$ & $125 \pm 13.2$ & $1822 \pm 36$ \\
10 & $17.5 \pm 2.2$ & $94 \pm 9.2$ & $1298 \pm 54$ \\
30 & $16.1 \pm 2.8$ & $106 \pm 13.2$ & $848 \pm 88$ \\
100 & $14.1 \pm 2.4$ & $102 \pm 5.2$ & $375 \pm 59$ \\
\hline
\end{tabular}

Cells were exposed to 3-300 $\mu \mathrm{M}$ ATP for $8 \mathrm{~d}$ (from day 1 after plating till confluence) and labeled with $\left[{ }^{35}\right.$ S]methionine for the last $48 \mathrm{~h}$. $\left[{ }^{35}\right.$ S $]$ methionine incorporation into cellular protein is expressed as percent change over control cells \pm SEM of triplicate determinations. The amount of $\left[{ }^{35} \mathrm{~S}\right]$ methionine incorporated into cellular proteins per microgram DNA of control cells was $115,644 \pm 2,240 \mathrm{cpm} / \mu \mathrm{g}$ DNA. Cornified envelopes were determined by dissolving the cells in SDS/DTT solution as described in Methods. The results are expressed as cpm $\left[{ }^{35} \mathrm{~S}\right]$ methionine incorporated into cornified envelopes per microgram DNA \pm SEM of triplicate determinations. Multivariable analysis of variance indicated that ATP had a significant inhibitory effect on cornified envelope formation $(P=0.001)$, but no inhibition of $\left[{ }^{35} \mathrm{~S}\right]$ methionine incorporation into total cell protein or alteration of DNA content. diated by the transient Cai increase, keratinocytes were preincubated with an intracellular calcium chelator, BAPTA AM, before ATP exposure. As shown in Table V, chelation of Cai with BAPTA reduced basal Cai levels by $40-45 \%$ and completely blocked Cai response to ATP. In the absence of BAPTA, ATP induced a $60 \%$ stimulation of $\left[{ }^{3} \mathrm{H}\right]$ thymidine incorporation into DNA. BAPTA inhibited the basal rate of DNA synthesis of cells by as much as $90 \%$ and blocked the ATP stimulated DNA synthesis.

Table III. Effect of ATP on DNA Content and DNA Synthesis of Keratinocytes

\begin{tabular}{rcc}
\hline ATP & DNA & $\begin{array}{c}{\left[{ }^{3} \mathrm{H}\right] \text { thymidine incorporation }} \\
\text { into DNA per microgram DNA }\end{array}$ \\
\hline$\mu M$ & $\mu g / d i s h$ & \\
0 & $20.5 \pm 1.1$ & $601 \pm 40$ \\
3 & $20.4 \pm 1.2$ & $763 \pm 34$ \\
10 & $19.0 \pm 1.6$ & $839 \pm 53$ \\
30 & $17.1 \pm 1.3$ & $914 \pm 41$ \\
100 & $21.3 \pm 1.7$ & $806 \pm 36$ \\
300 & $19.0 \pm 1.7$ & $916 \pm 87$ \\
\hline
\end{tabular}

Keratinocytes grown in KGM containing $1.2 \mathrm{mM}$ calcium were exposed to 3-300 $\mu \mathrm{M}$ ATP for $2 \mathrm{~d}$ at $80 \%$ confluence. The cells were labeled with $\left[{ }^{3} \mathrm{H}\right]$ thymidine for $3 \mathrm{~h}$ following ATP exposure, and the amount of $\left[{ }^{3} \mathrm{H}\right]$ thymidine incorporated into the TCA-precipitated macromolecules was measured. The results are expressed as mean of triplicate dishes \pm SEM. ATP had a significant stimulatory effect on $\left[{ }^{3} \mathrm{H}\right]$ thymidine incorporation $(P=0.002)$ which increased with ATP concentration. ATP had no significant influence on DNA content of keratinocytes. 
Table IV. Effect of ATP, BPE, and FCS on DNA Synthesis and DNA Content of Keratinocytes

\begin{tabular}{lllc}
\hline & $\begin{array}{c}\left.{ }^{3} \mathrm{H}\right] \text { thymidine } \\
\text { into DNA }\end{array}$ & $\begin{array}{c}\text { Nuclear } \\
\text { labeling }\end{array}$ & DNA content \\
\hline Control & $100 \pm 10.1$ & $100 \pm 15$ & $100 \pm 22.8$ \\
ATP $(100 \mu \mathrm{M})$ & $149 \pm 31.6^{*}$ & $122 \pm 20^{*}$ & $82 \pm 25^{\ddagger}$ \\
BPE $(70 \mu \mathrm{g} / \mathrm{ml})$ & $257 \pm 19.3^{\S}$ & $170 \pm 11.8^{\S}$ & $245 \pm 23^{\S}$ \\
FCS $(1.0 \%)$ & $275 \pm 90.1^{\S}$ & $168 \pm 5.9^{\S}$ & $294 \pm 31^{\S}$ \\
\hline
\end{tabular}

Keratinocytes were grown in KGM containing $0.07 \mathrm{mM}$ calcium in six well multiwells (for $\left[{ }^{3} \mathrm{H}\right]$ thymidine incorporation and DNA content) or in four well-chamber slides (for nuclear labeling). For $\left[{ }^{3} \mathrm{H}\right]$ thymidine incorporation studies, cells were grown for six days of which four days were in the presence of BPE and the last two days in the absence of BPE. On day 6, medium was changed and cells treated with either nothing (control), $100 \mu \mathrm{M} \mathrm{ATP,} 70 \mu \mathrm{g} / \mathrm{ml}$ BPE, or $1 \% \mathrm{FCS}$ for $4 \mathrm{~h}$. $\left[{ }^{3} \mathrm{H}\right]$ Thymidine $(2 \mu \mathrm{Ci} / \mathrm{ml})$ was included in the medium for last two hours of incubation. For determining the effect of various agents on DNA content, cells were grown for three days with BPE and then for a further five days without BPE but with the various agents. ATP, BPE, or FCS was readded at every medium change. Data are the mean of triplicate determinations $\pm S D$. Nuclear labeling was from the experiment of Fig. 7 after counting five different fields under the microscope. Data are expressed as percentage of controls. Absolute values for the controls are: DNA content, 8.33 \pm 1.9 $\mu \mathrm{g} / \mathrm{dish} ;\left[{ }^{3} \mathrm{H}\right]$ thymidine incorporation, $161.8 \pm 16.8 \mathrm{cpm}$ incorporated/ $\mu$ g DNA; and nuclear labeling, $22 \pm 3.3 \%$ cells. ${ }^{\S} P<0.01 ;{ }^{*} P$ $<0.05$; ${ }^{\ddagger}$ not significant when compared to control.

\section{Discussion}

The results of the present studies indicate the presence of receptors specific for ATP ( $\mathrm{P}_{2}$ subclass of purinergic receptors) on the keratinocyte cell surface which mediate the effect of extracellular ATP. ATP increased Cai of keratinocytes by spectrofluorimetric measurements of cell suspensions and of single cells in culture. The magnitude of the increase appears to be greater in attached cells compared to cell suspensions. Whether this represents a change in cell behavior upon trypsinization (such as a loss of ATP receptors) is not known. ATP raises Cai

Table V. Effect of Calcium Chelation on Cai and DNA Synthesis

\begin{tabular}{lcccc}
\hline & -ATP & +ATP & $\begin{array}{c}\text {-ATP } \\
\text { +BAPTA }\end{array}$ & $\begin{array}{c}\text { +ATP } \\
\text { +BAPTA }\end{array}$ \\
\hline $\begin{array}{l}\text { Rate of } \\
\text { DNA synthesis }\end{array}$ & $100 \pm 8.9$ & $159 \pm 28$ & $7.4 \pm 4$ & $9.6 \pm 5.1$ \\
$\begin{array}{l}\text { Cai (peak) } \\
(n M)\end{array}$ & $150 \pm 28$ & $386 \pm 40$ & $86 \pm 7.1$ & $92 \pm 18$
\end{tabular}

Rate of DNA synthesis (expressed as percentage of control) was determined by $\left[{ }^{3} \mathrm{H}\right]$ thymidine incorporation into total cellular DNA as described in Methods. $\left[{ }^{3} \mathrm{H}\right]$ Thymidine incorporation by control cultures (-ATP) was $4,350 \pm 390 \mathrm{cpm} / \mathrm{dish}$. Cai was determined in keratinocytes loaded with $1 \mu \mathrm{M}$ Indo-1. BAPTA (18 $\mu \mathrm{M})$ and ATP. (100 $\mu \mathrm{M})$ were added $24 \mathrm{~h}$ before harvest for $\left[{ }^{3} \mathrm{H}\right]$ thymidine incorporation. BAPTA was added 2 min before ATP addition to the cell suspensions for Cai measurements. Results are the mean \pm SD of triplicate determinations. of keratinocytes by releasing calcium solely from intracellular sources as evidenced by the observation that EGTA does not decrease the magnitude of the response and that ATP does not increase the Mn quenching or increase propidium iodide fluorescence. Since ATP increases $\mathrm{IP}_{3}$ levels in parallel with the increase in Cai, it is tempting to conclude that the intracellular source of the Cai must be either endoplasmic reticulum or other $\mathrm{IP}_{3}$-sensitive calcium pools such as calciosomes (48). However, ATP does not release the total releasable pool of intracellular calcium since ionomycin addition subsequent to a second ATP addition (which had no further effect) evoked a pronounced Cai increase in the presence of EGTA. The variable cellular response to ATP as seen in the calcium imaging analysis appears to be due to differences in the way cells handle increased Cai. Keratinocytes differ in their ability to return the elevated Cai to the baseline even when the increase in Cai is brought about by the calcium ionophore, ionomycin. These may reflect differences in the phases of calcium oscillations in the cell or variations in calcium sequestration by endoplasmic reticulum and/or calcium efflux at the plasma membrane. Whether keratinocytes vary in their ATP-mediated calcium release from intracellular sources and whether this heterogeneity reflects differences in the degree of differentiation of the cells needs further controlled studies. However, such heterogeneous cellular responses to ATP have been reported for rat liver epithelial cells (18).

Extracellular ATP increases Cai in a variety of cells. In other cell systems, ATP increases Cai by increasing intracellular mobilization (45), by influx of calcium through ATP-regulated plasma membrane calcium channels (16), or by nonspecific leakage of calcium into cells (49). In HL-60 (20) and Ehrlich ascites tumor cells (45) ATP-stimulated $\mathrm{IP}_{3}$ turnover is only partly responsible for the Cai increase. ATP also increases calcium flux across the plasma membrane of these cells. In rat adipocytes ATP stimulates calcium influx by opening a calcium channel (17). Extracellular ATP and some of its analogues (UTP, ITP, AMP-PNP) induce transient rises in Cai of canine keratinocytes by releasing Cai from intracellular stores in an extracellular calcium concentration-dependent manner (21). In other cell systems ATP has a nonlethal permeabilizing effect (3T6, SV40-3T3) which may lead to the rise in Cai (1). To our knowledge, keratinocytes appear to be the only cell system in which extracellular ATP increases Cai exclusively by release of Cai from intracellular sources.

Micromolar concentrations of extracellular ATP influence a variety of biological processes, stimulating histamine secretion from mast cells, increasing membrane permeability, stimulating endothelium-dependent vasodilation, inhibiting antibody-dependent cytotoxicity, and acting as a neurotransmitter (reviewed in reference 1). Several recent studies suggest that ATP, acting via $P_{2}$ purinergic receptors, acts as a mitogen for several cell types (3T3, A431, DDt-MF2, HFF) (22-25). Adenosine as well as ATP interacts with $P_{1}$ purinergic receptors while effects of adenine nucleotides are mediated by $P_{2}$ purinergic receptors (1). The fact that ATP and to some extent ADP, but not AMP, and adenosine stimulate the Cai response in keratinocytes suggests that the $P_{2}$ purinergic receptors of keratinocytes belong to the $P_{2 y}$ subclass $(1,46)$. The nonresponsiveness to the different adenosine analogues, nucleotide monophosphates, and inorganic pyrophosphates again indicates the specificity for $\mathrm{P}_{2}$ purinergic receptors. UTP and ITP are equally 

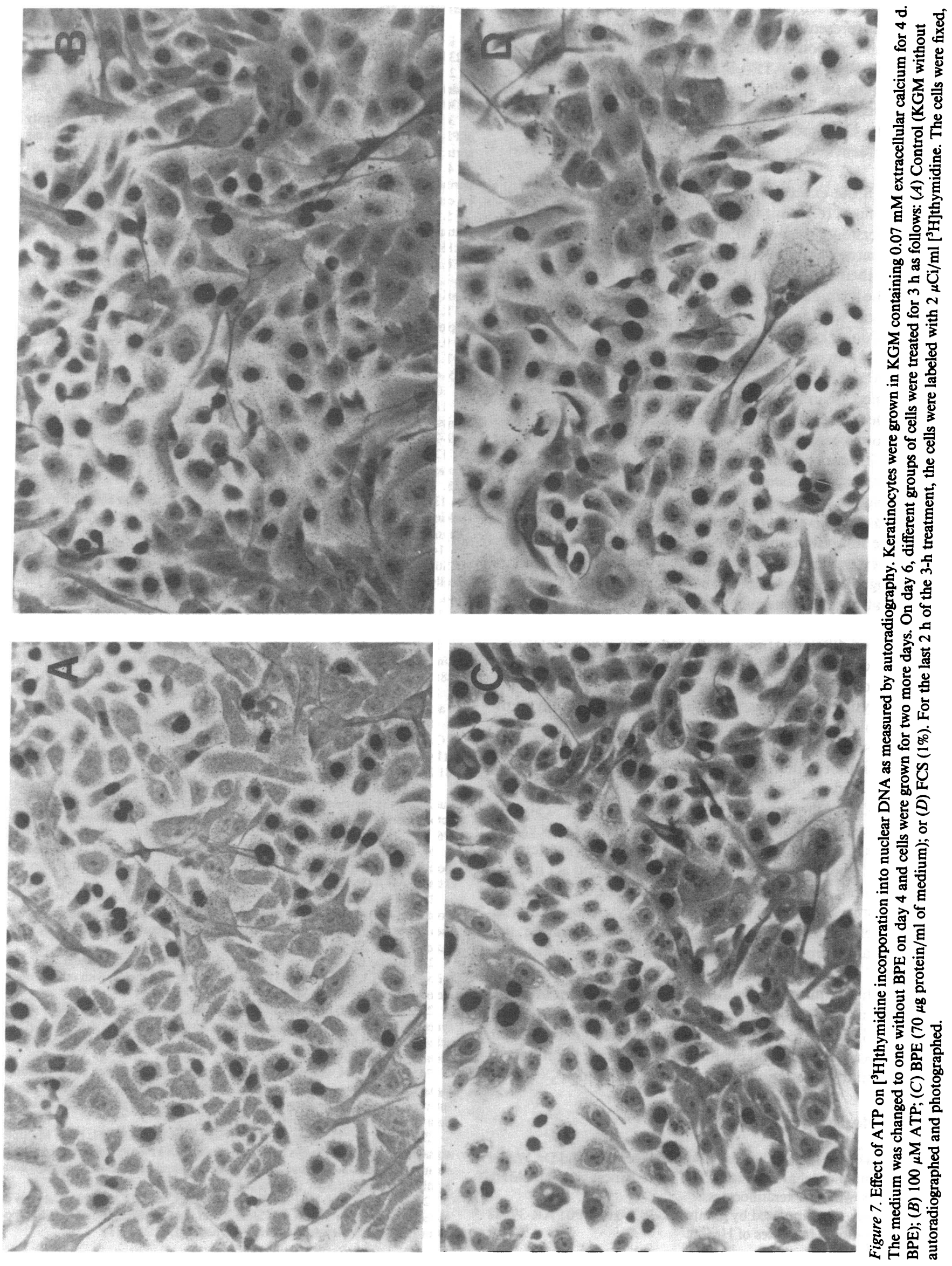
effective as ATP in activating $P_{2}$ purinergic receptors in human keratinocytes (present study) as well as in canine keratinocytes (21). The rapid response to the poorly hydrolyzable ATP analogues, AMP-PNP and ATP- $\gamma$ S, rule out the requirement of ATP hydrolysis for the Cai response. The GTP and CTP responses which appear to be independent of $\mathrm{P}_{2}$ receptors may represent the GTP-mediated calcium exchange between agonist-independent and agonist-dependent pools within the cytosol (50).

Although the exact mechanisms by which ATP exerts its biological effects (e.g., mitogenic response) on target cells are poorly understood, they might, at least in part, be regulated by changes in intracellular calcium. Keratinocytes are sensitive to changes in their Cai levels in that a sustained increase in Cai increases the terminal differentiation of these cells (33-35). Extracellular calcium and calcium ionophores induce terminal differentiation of keratinocytes by a sustained increase in their Cai levels (38). In contrast, ATP increases Cai of keratinocytes in an acute and transient fashion which is associated with a transient increase in DNA synthesis and a decrease in differentiation. The transient increase in Cai in association with activation of protein kinase $C(24)$ or stimulation of prostaglandin synthesis (25) may trigger DNA synthesis and inhibit differentiation of these cells. Chelation of Cai, in addition to decreasing both the basal Cai and abolishing the ATP-mediated transient increase in Cai, decreases basal and ATP-stimulated DNA synthesis. The inhibition of the proliferative response to ATP by buffering cytosolic calcium favors the view that intracellular calcium signals are associated with ATP-induced DNA synthesis of keratinocytes. The mechanism by which ATP inhibits differentiation of keratinocytes is not clear at present. Cell proliferation and differentiation usually follow an inverse relationship. Conceivably, ATP prevents the sustained increase in Cai that appears to be required for differentiation.

The physiological relevance of these observations may stem from the role of ATP in wound healing. During wounding, one of the first steps is the release of thrombin, and aggregation and degranulation of platelets (51). Platelets, in addition to releasing PDGF and TGF- $\alpha(52,53)$, also release ATP and ADP from the alpha granules (22). Both PDGF and TGF- $\dot{\alpha}$ stimulate fibroblast proliferation and induce synthesis of new extracellular matrix (53). ATP and ADP released by the platelets are mitogenic to both fibroblasts and keratinocytes and act in concert with other growth factors $(22,23)$. In addition, ATP (and possibly other cytokines) inhibit keratinocyte differentiation immediately following wounding, thereby accelerating the wound healing process. The concentration of ATP reported at the site of platelet aggregation, $10-30 \mu \mathrm{M}(1)$, is in the same range as that required by keratinocytes for induction of DNA synthesis, inhibition of differentiation, and stimulation of Cai and $\mathrm{IP}_{3}$. Therefore, it is attractive to postulate that extracellular ATP plays a role in wound healing by modulating keratinocyte growth and differentiation via changes in Cai and $\mathrm{IP}_{3}$.

\section{Acknowledgments}

We appreciate the helpful discussions of Dr. Peter Elias and Dr. Walter Holleran and the technical assistance of Mara Hincenbergs and Mark Bogan in growing the keratinocytes.

This work was supported by grants AR-38360 and P01 AR-39448 from the National Institutes of Health.

\section{References}

1. Gordon, J. L. 1986. Extracellular ATP: effects, sources and fate. Biochem. J. 233:309-319.

2. Macfarlane, D. E., and D. C. B. Mills. 1975. The effects of ATP on platelets: evidence against the central role of released ADP in primary aggregation. Blood. 46:309-320.

3. Martin, W., N. J. Cusack, J. S. Carleton, and J. L. Gordon. 1985. Specificity of P2-purinoreceptor that mediates endothelium-dependent relaxation of the pig aorta. Eur. J. Pharmacol. 108:295-299.

4. Kennedy, C., and G. Burnstock. 1985. ATP produces vasodilation via p1 purinoreceptors and vasoconstriction via p2 purinoreceptors in the isolated rabbit central ear artery. Blood Vessels. 22:145-155.

5. Potter, D. D., E. J. Furshpan, and S. C. Landis. 1983. Transmitter status in cultured rat sympathetic neurons: plasticity and multiple functions. Fed. Proc. 42:1626-1632.

6. Burnstock, G. 1971. Neural nomenclature. Nature (Lond.). 229:282-283.

7. Burnstock, G. 1975. Comparative studies of purinergic nerves. J. Exp. Zool. 194:103-134.

8. Ingerman, C. M., J. B. Smith, and M. J. Silver. 1979. Direct measurement of platelet secretion in whole blood. Thromb. Res. 16:335-344.

9. George, J. N. 1985. In Platelet Membrane Glycoproteins. J. N. George, A. T. Nurden, and D. R. Phillips, editors. Plenum Publishing Corp., New York. 395-412.

10. Burnstock, G. 1972. Purinergic nerves. Pharmacol. Rev. 24:500-581.

11. Smith, A. D. 1968. In The Interaction of Drugs and Subcellular Components in Animal Cells. P. N. Campbell, editor. Churchill Livingstone, Edinburgh. 239-292.

12. Burnstock, G. 1978. In Cell Membrane Receptors for Drugs and Hormones. R. W. Straub and K. Bolis, editors. Raven Press, Ltd., New York. 107118.

13. Cockcroft, S., and B. D. Grumperts, 1979. Activation and inhibition of calcium-dependent histamine secretion by ATP ions applied to rat mast cells. $J$. Physiol. (Lond.). 296:229-243.

14. Cusack, N. J., S. M. O. Hourani, and L. A. Welford. 1985. In Mechanisms of Stimulus-Response Coupling in Platelets. J. Westwick, D. E. MacInture, N. F. Scully, and V. V. Kakkar, editors. Plenum Publishing Corp., New York. 128146.

15. Collis, M. G. 1985. In Purines: Pharmacology and Physiological Roles. T. W. Stone, editor. Macmillan Publishers Ltd., London. 75-84.

16. Benham, C. D., and R. W. Tsien. 1987. A novel receptor-operated calcium-permeable channel activated by ATP in smooth muscle. Nature (Lond.). 328:375-377.

17. Kelly, K. L., J. T. Deeney, and B. E. Corkey. 1989. Cytosolic free calcium in adipocytes. J. Biol. Chem. 264:12754-12757.

18. Boynton, A. L., R. V. Cooney, T. D. Hill, T. Nilsson, P. Arkhammar, and P. O. Breggren. 1989. Extracellular ATP mobilizes intracellular calcium in T51B rat liver epithelial cells: a study involving single cell measurements. Exp. Cell Res. 181:245-255.

19. Gonzalez, F. A., D. J. Gross, L. A. Heppel, and W. W. Webb. 1988. Studies on the increase in cytosolic free calcium induced by epidermal growth factor, serum, and nucleotides in individual A 431 cells. J. Cell. Physiol. 135:269276.

20. Dubyak, G. R., D. S. Cowen, and L. M. Meuller. 1988. Activation of Inositol phospholipid breakdown in HL 60 cells by P2-purinergic receptors for extracellular ATP. J. Biol. Chem. 263:18108-18117.

21. Suter, M. M., F. M. Crameri, J. P. Slattery, P. J. Millard, and F. A. Gonzalez. 1991. Extracellular ATP and some of its analogues induce transient rises in cytosolic free calcium in individual canine keratinocytes. J. Invest. Dermatol. 97:223-229.

22. Huang, N., D. Wang, and L. A. Heppel. 1989. Extracellular ATP is a mitogen for 3T3, 3T6, and A 431 cells and acts synergistically with other growth factors. Proc. Natl. Acad. Sci. USA. 86:7904-7908.

23. Wang, D., N. Huang, and L. A. Heppel. 1990. Extracellular ATP shows synergistic enhancement of DNA synthesis when combined with agents that are active in wound healing or as neurotransmitters. Biochem. Biophys. Res. Commun. 166:251-258.

24. Wang, D., N. Huang, F. A. Gonzalez, and L. A. Heppel. 1991. Multiple signal transduction pathways lead to extracellular ATP-stimulated mitogenesis in mammalian cells. 1 . Involvement of protein kinase $\mathrm{C}$-dependent and independent pathways. J. Cell. Physiol. 146:473-482.

25. Huang, N., D. Wang, F. A. Gonzalez, and L. A. Heppel. 1991. Multiple signal transduction pathways lead to extracellular ATP-stimulated mitogenesis in mammalian cells. 2 . A pathway involving arachidonic acid release, prostaglandin synthesis and cyclic AMP accumulation. J. Cell. Physiol. 146:483-494.

26. Moolenaar, W. H., L. H. K. Defize, and S. W. De Latt. 1986. Calcium in the action of growth factors. In Calcium and the Cell. Ciba Foundation Symposium 122. John Wiley \& Sons Ltd., Chichester, UK. 212-231. 
27. Exton, J. H. 1986. Mechanisms involved in calcium mobilizing agonist responses. Adv. Cyclic Nucleotide Protein Phosphorylation Res. 20:211-262.

28. Lew, D. P. 1989. Receptor signalling and intracellular calcium in neutrophil activation. Eur. J. Clin. Invest. 19:338-346.

29. Hepler, P. K. 1989. Calcium transients during mitosis: observations in flux. J. Cell Biol. 109:2567-2573.

30. Hepler, P. K., and S. M. Wolniak. 1983. Membranous compartments and ionic transients in the mitotic apparatus. In Modern Cell Biology. Vol. 2. J. R. McIntosh, editor. Alan R. Liss, Inc., New York. 93-112.

31. Poenie, M., J. Alderton, R. Y. Tsien, and R. A. Steinhardt. 1985. Changes of free calcium levels with stages of the cell division cycle. Nature (Lond.). 315:147-149.

32. Tombes, R. M., and G. G. Borisy. 1989. Intracellular calcium and mitosis in mammalian cells: anaphase onset is calcium modulated, but is not triggered by a brief transient. J. Cell Biol. 109:627-636.

33. Hennings, H., D. Michael, C. Cheng, P. Steinert, K. Holbrook, and S. H. Yuspa. 1980. Calcium regulation of growth and differentiation of mouse epidermal cells in culture. Cell. 19:245-254.

34. Pillai, S., D. D. Bikle, M. Hincenbergs, and P. M. Elias. 1988. Biochemical and morphological characterization of growth and differentiation of normal human neonatal keratinocytes in a serum-free medium. J. Cell. Physiol. 134:229237.

35. Pillai, S., D. D. Bikle, M.-L. Mancianti, P. Cline, and M. Hincenbergs. 1990. Calcium regulation of growth and differentiation of normal human keratinocytes: modulation of differentiation competence by stages of growth and extracellular calcium. J. Cell. Physiol. 143:294-302.

36. Hennings, H., F. H. Krwzewski, S. H. Yuspa, and R. W. Tucker. 1989. Intracellular calcium alterations in response to extracellular calcium in normal and neoplastic keratinocytes. Carcinogenesis (Eynsham). 10:777-780.

37. Sharpe, G. R., J. I. Gillespie, and J. R. Greenwell. 1989. An increase in intracellular calcium is an early event during differentiation of cultured human keratinocytes. FEBS (Fed. Eur. Biochem. Soc.) Lett. 254:25-28.

38. Pillai, S., and D. D. Bikle, 1989. A differentiation-dependent, calcium sensing mechanism in normal human keratinocytes. J. Invest. Dermatol. 92:500A. (Abstr.)

39. Grynkiewicz, G., M. Poenie, and R. Y. Tsien. 1985. A new generation of calcium indicators with greatly improved fluorescence properties. J. Biol. Chem. 260:3440-3447.
40. Berridge, M. J., R. M. C. Dawson, C. P. Downes, J. P. Heslop, and R. F. Irvine. 1983. Changes in the level of inositol phosphates after agonist-dependent hydrolysis of membrane phosphoinositides. Biochem. J. 212:473-482.

41. Labarca, C., and K. Paigen. 1980. A simple, rapid and sensitive DNA assay procedure. Anal. Biochem. 102:344-352.

42. King, I., S. L. Mella, and A. L. Sartorelli. 1986. A sensitive method to quantify the termial differentiation of cultured epidermal cells. Exp. Cell Res. $167: 252-256$.

43. Hallam, T. J., and T. J. Rink. 1985. Agonists stimulate divalent cation channels in the plasma membrane of human platelets. FEBS (Fed. Eur. Biochem. Soc.) Lett. 186:175-179.

44. Berridge, M. J., and R. F. Irvine. 1984. Inositol trisphosphate, a novel second messenger in cellular signal transduction. Nature (Lond.). 312:315-317.

45. Dubyak, G. R. 1985. Extracellular ATP activates polyphosphoinositide breakdown and calcium mobilization in Ehrlich ascites tumor cells. Arch. Biochem. Biophys. 245:84-95.

46. Pirotton, S., E. Rashp, D. Demolle, C. Erneux, and J. M. Boeynaems 1987. Involvement of inositol 1,4,5 bis phosphate and calcium in the action of adenine nucleotides on aortic endothelial cells. J. Biol. Chem. 262:17461-17466.

47. Watt, F. W. 1983. Involucrin and other markers of keratinocyte terminal differentiation. J. Invest. Dermatol. 81:100-103S.

48. Volpe, P., K. Krause, S. Hashimoto, F. Zorzato, and T. Pozzan, 1988. "Calciosome," a cytoplasmic organelle: the inositol 1,4,5 trisphosphate-sensitive calcium store of nonmuscle cells? Proc. Natl. Acad. Sci. USA. 85:1091-1095.

49. Dicker, P., L. A. Heppel, and E. Rozengurt. 1980. Control of membrane permeability by external and internal ATP in 3T6 cells grown in serum-free medium. Proc. Natl. Acad. Sci. USA. 77:2103-2107.

50. Koshiyama, H., and A. H. Tashjian. 1991. Control of intracellular calcium redistribution by guanine nucleotides and inositol 1,4,5 trisphosphate in permeabilized GH4Cl cells. Endocrinology. 128:2715-2722.

51. Dijke, P. T., and K. K. Iwata. 1989. Growth factors for wound healing. Bio/technology. 7:793-798.

52. Ross, R., E. W. Raines, and D. F. Bowen-Pope. 1986. The biology of platelet-derived growth factor. Cell. 46:155-169.

53. Sporn, M. B., A. B. Roberts, L. M. Wakefield, and B. de Crombrugghe. 1987. Some recent advances in the chemistry and biology of transforming growth factor- $\beta$. J. Cell Biol. 105:1039-1045. 